\title{
NOTE ON THE ILLUSTRATIONS
}

The frontispiece by Sir Joshua Reynolds (courtesy of the Scottish National Portrait Gallery, Edinburgh) portrays William Robertson with clerical gown, writing materials, and powdered wig symbolic of the Moderates' commitment to religion, learning, and politeness, respectively. First exhibited at the Royal Academy in 1772, it depicts the university principal at the height of his power and influence and admirably captures both his intelligence and craftiness.

Besides Reynolds (who also painted a portrait of Adam Ferguson that may now be lost), artists such as David Martin, William Millar, Sir Henry Raeburn, and Archibald Skirving painted the subjects of this book at various times in their lives. Several of their works-including Millar's pleasant portrait of John Home at the age of forty, Martin's two splendid portraits of Alexander Carlyle in his prime, Skirving's striking portrait of Carlyle near the end of his life, and Raeburn's full-length portrait of a heavy-set, baggy-eyed Hugh Blair-are reproduced in James Kinsley's edition of Carlyle's Anecdotes and Characters of the Times (London, 1973); others, such as Raeburn's fine portraits of Ferguson and Robertson from the early 1790s (both on display at the University of Edinburgh, as is Martin's mid-1770s portrait of Blair with hand on heart), may be found in various other publications.

The illustrations on pages 142-46 in this book reveal different aspects of the personalities and appearances of the Moderate literati of Edinburgh. The portrait of Adam Ferguson by William Millar (1763; courtesy of a private Scottish collection) shows the professor at the age of forty, the year before his switch from the natural philosophy to the moral philosophy chair at the University of Edinburgh. Millar's portrait of William Robertson on the next page (courtesy of a private Scottish collection) probably dates from the same period, when its subject was just beginning his illustrious academic career. John Home is perhaps sixty years old in the Raeburn portrait that follows (courtesy of Mr. Guy RossLowe of Malpas, Cheshire). This is neither the sprightly young playwright whose entrance into company Alexander Carlyle once compared to "opening a window and letting the sun into a dull room," nor the sad, worn-out old man pictured in a Raeburn painting of Home in the National Portrait Gallery, London. Raeburn painted two excellent, yet 
very different, late eighteenth-century portraits of Hugh Blair in the identical pose (seated with hands clasped, looking to the right): in one of them (current whereabouts unknown) Blair dons a powdered wig and clerical gown; in the other (reproduced below from a private collection) he wears an ordinary suit and an elegant velvet nightcap. The portrait that Raeburn painted of Alexander Carlyle at a stately seventy-four years of age (1796; courtesy of the present earl of Haddington, whose ancestor of that title commissioned it) demonstrates why Carlyle's appearance as an older man was sometimes likened to that of the Roman god Jupiter ("the grandest demigod I ever saw," Sir Walter Scott said of him in this context). But good looks were no defense against the witty caricaturist John Kay, whose satirical etching "Faithful Service Rewarded" (1793; reproduced from Kay's Series of Original Portraits and Caricature Etchings, 2 vols. [Edinburgh, 1837-1842], 2:118) renders Carlyle and fellow Moderate Henry Grieve not as gods or demigods but as asses ridden by Scotland's political boss, Henry Dundas.

Other likenesses of the Moderate literati of Edinburgh, including pencil and chalk drawings, medallions, engravings, and additional caricature etchings by John Kay, are listed by Elaine Kilmurray in volume 2 of the Dictionary of British Portraiture, ed. Richard Ormond and Malcolm Rogers, 4 vols. (London, 1979). 